\title{
The Impact of Vocational Teacher Training Program (BIGV) Towards the Development of Interpersonal Communication Skills Among Prospective Vocational Teachers
}

\author{
Hasyamuddin Othman, Norathirah Nabila Abd Mutalib, Reyanhealme Rohanai
}

\begin{abstract}
Malaysia is generally one of the earliest countries in designing a higher education system that highlights the elements and challenges of Industry 4.0 issues, as already outlined and addressed in the 2015-2025 Malaysian Education Plan (Higher Education). As such, the self-development of teachers' human resources especially in the aspects of teacher communication skills has been developed and fully implemented in this Vocational Teacher Training Program (BIGV) curriculum. This program is a compulsory subject that must be taken by Bachelor Degree Teacher program in all Malaysia's Universities. The sample of the study consists of 200 respondents divided into two groups that refers to the design of the experimental quasi study which is an experimental group of 158 prospective vocational teachers undergoing a comprehensive Bilingual Vocational Teacher Training (BIGV) program from the second semester student at the Faculty of Technical and Vocational Education, UTHM and control group of 42 prospective vocational teachers from second semester student in the Faculty of Technical and Vocational, UPSI. This research aims to study the effectiveness of Vocational Teacher Training (BIGV) Program towards developing the interpersonal communication skills acquisition level among the prospective vocational teachers. The researchers analyzed pre-test and post-test findings from both groups using the T-Test analysis. The results of the analysis showed that there was no significant difference in the number of min scores in pre-test and post-test for the two groups. Therefore, a further comprehensive action is needed to ensure that the implementation of the Vocational Teacher Training Program (BIGV) is successful to meet its objective in producing a more credible and sustainable teacher in the future.
\end{abstract}

Keywords: Program Bina Insan Guru Vokasional (BIGV), prospective vocational teacher, Quasi-experimental, Interpersonal Communication Skills.

Revised Manuscript Received on February 18, 2020.

* Correspondence Author

Hasyamuddin Othman*, Faculty of Technical and Vocational Email: hasyam@uthm.edu.my

Norathirah Nabila Abd Mutalib, Faculty of Technical and Vocational Education, Universiti Tun Hussein Onn Malaysia, 86400, Batu Pahat, Johor. Email: athirah.abdmutalib@gmail.com

Reyanhealme Rohanai, Faculty of Technical and Vocational Education, Universiti Tun Hussein Onn Malaysia, 86400, Batu Pahat, Johor. Email: reyanrohanai@gmail.com

(C) The Authors. Published by Blue Eyes Intelligence Engineering and Sciences Publication (BEIESP). This is an open access article under the CC BY-NC-ND license (http://creativecommons.org/licenses/by-nc-nd/4.0/) Education, Universiti Tun Hussein Onn Malaysia, 86400, Batu Pahat, Johor.

\section{INTRODUCTION}

Educator or teacher is one of important elements in education system and plays role to aid in the development of his or her students' personalities and specific related knowledge competency. An effective educator should impart with good interpersonal skills in ensuring their teaching and learning process runs in interactive way and went as per planned (Ulah et al., 2012). This is however, issues on the abilities of educator now has been challenged from many parties. There were some claims stated that the current educators have a low acquisition in teaching and learning style and their teaching skills were set to be at the moderate level (Kementerian Pengajian Tinggi Malaysia \& Kementerian Pelajaran Malaysia, 2005). Moreover, a lower readiness of educators and the lacking of knowledge and skills towards subject matters had affect educators' quality in teaching delivery.

In ideal situation, an educator must have a good capabilities and dynamic personality in enriching their teaching and learning session. As in Industrial Revolution 4.0 (IR 4.0), the needs on updating subject syllabus to meet current technological application such as online media interactive classes or internet of thinking application (IoT) within teaching and learning session are seems very crucial. It may increase students' participation during class session but at the same time it gives an educator a great challenge in ensuring themselves prepared within the current expectations. Perhaps, an application of comprehensive knowledge transfers through potential improvement program among current or future educator should be conducted. It was proven that this improvement program able to improvise educator potential in their communication skill aspect especially embarking an effective communication within organization and teaching delivery (Tengku Kasim \& Abdulajak, 2018). In conjunction with this finding, it can be seen that this improvement teaching program seems important in determining the quality level of educator. In current Malaysian education system itself, a preparatory program for prospective teachers has been conducted as early in university studies and it requires education student to undertakes this subject during specific year of study.

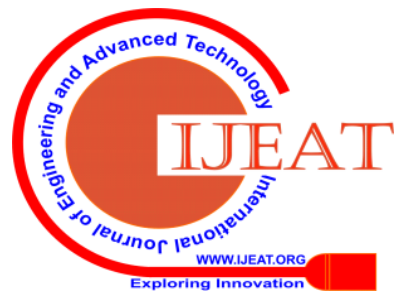


This preparatory program known as Bina Insan Guru Vokasional (BIGV) or can be translated as Vocational Teacher Training Program. This program is expected helps to nurture a good quality of prospective vocational teachers and empowering teacher interpersonal communication skills, social awareness and thinking style.

As a result, a prospective teacher may able to deliver a good teaching style and capable to develop an effective learning session (Ilias et al., 2016).

\section{A. Research Purpose}

This research aims to identify the effectiveness of Vocational Teacher Training Program (BIGV) towards improving interpersonal communication skills among prospective vocational teachers. Moreover, this research is expected to increase the awareness among prospective vocational teachers in developing their interpersonal communication skills throughout activities performed in this BIGV program. Perhaps, students would appreciate all the knowledge gained and take opportunities to polish their communication skills when being as a teacher in the future. This study also aims to provide a significant benchmark on the effectiveness of current BIGV program performed and enrich suggestion about potential activities that may help in maximizing the quality of the program.

\section{LITERATURE REVIEW}

\section{A. Vocational Teacher Training Program (BIGV)}

Teacher training program in higher education provides a good platform in preparing prospective vocational teacher with the basic of teaching and competency needed being as a teacher. This program includes potential activities such as seminar and motivation camp that helps to increase the confident level and communication skills among prospective teacher. Unfortunately, there were some reports stated that prospective teachers nowadays have a lack of confident level and failed to plays a good role as teacher in delivering knowledge and developing students' attitude. This problem could be caused by the poor understanding in translating theoretical knowledge of pedagogy in real teaching environment. In accordance to this situation, an initiative in increasing self-development among prospective teachers in terms of attitude and soft skills are seems important. As in BIGV program itself, the development of soft skills among prospective teachers are being set to be prioritized and the empowerment upon the implemented activities shall be takes place whenever needed. Within this goal definition, it was believed that this BIGV program provides a strong platform for the education institution in strengthen the needs of soft skills and attitudes as a teacher and at the same time exposing students with actual teaching experience through beneficial activities during the program takes place (Mohamed, et. al, 2014).

\section{B. Interpersonal Communication Skill}

According to the study performed by Widya (2013), interpersonal communication skills can be beneficial in many ways:

1. Good interpersonal communication skill is very important in improvise student knowledge in teaching delivery.

2. The use of proper language in communication is vital in teaching and learning session.

3. An effective teaching delivery able to increase motivation among students and it can be happened through a good interpersonal communication among teachers.

In details, interpersonal skill consists of several elements that includes three main aspect which is leadership, teamwork and networking. It integrates the development of individual's quality and sharpen soft skill in communication. Fig. 1 below shows the overall of elements lies within human interpersonal skill.

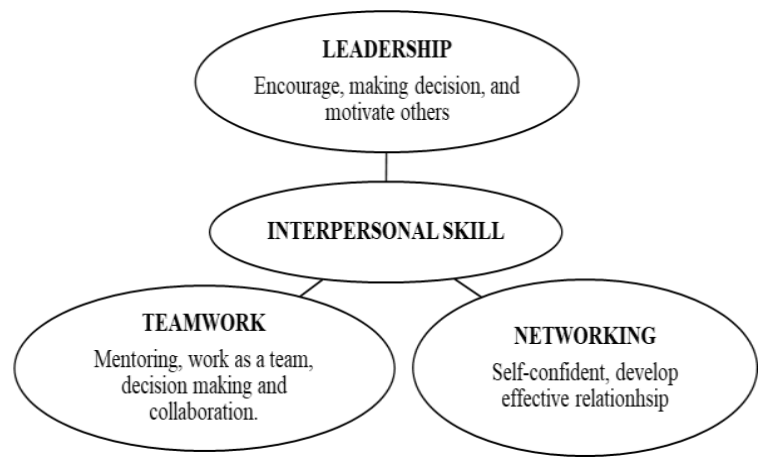

Fig.1 Interpersonal Skills Aspect

Musa \& Halim (2015) stated that teacher shall increase the acquisition level of interpersonal communication as it helps to increase the effectiveness of teaching and learning session either in or outside of class room teaching. Moreover, communication plays an important role in learning and teaching session as it imparts with the interaction between teacher and students in almost of learning session time. Therefore, the more effective communication produced by a teacher the better teaching and learning session could be held (Guat, 2013).

\section{METHODOLOGY}

The main methodology on this research lies on the application Quasi-experimental to identify the effectiveness of BIGV program among prospective teachers (education student) in selected Malaysia's higher education. Quasi-experimental has been widely used to replicate the real experiment setting in selecting sample population especially when random sampling population is possible to be taken (Chua, 2006). In details, this study involves two sample groups setting named as control group and experiment group. Researcher has prepared two types of test which is pre-test and post-test to identify level acquisition of interpersonal communication skill among two groups of samples. The sample of the study consists of 200 respondents divided into two groups where experimental group involves 158 education students second semester from Faculty of Technical and Vocational Education, UTHM and control group of 42 education students second semester from Faculty of Technical and Vocational, UPSI. 
Pre-test has been used to identify current acquisition level of interpersonal communication skill before undergoes BIGV program meanwhile post-test has been used to identify the new acquisition level of interpersonal communication skill after undergoes BIGV program. The data collection has been conducted for about two months involving two different test setting and the design of quasi-experimental can be stated as Fig. 2 below:

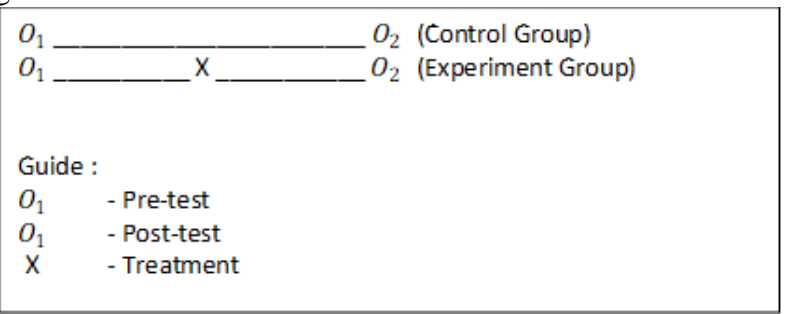

Fig. 2: Quasi-experimental research design (Source: Campbell \& Stanley, 1963)

Furthermore, in order to ensure that this research runs smoothly as per planned, a conceptual framework has been earlier developed by the researcher. This framework has been adapted from Dale (1956) and Md Salleh (1995) and has been modified to meet research constraints. This research basically starts with the pre-test evaluation that being conducted at the earlier stage of BIGV program and then post-test will be evaluated right after both sample groups has undergoes input \& throughput of teaching and learning session and as well as starts to gain output from the BIGV program as shown in Fig.3

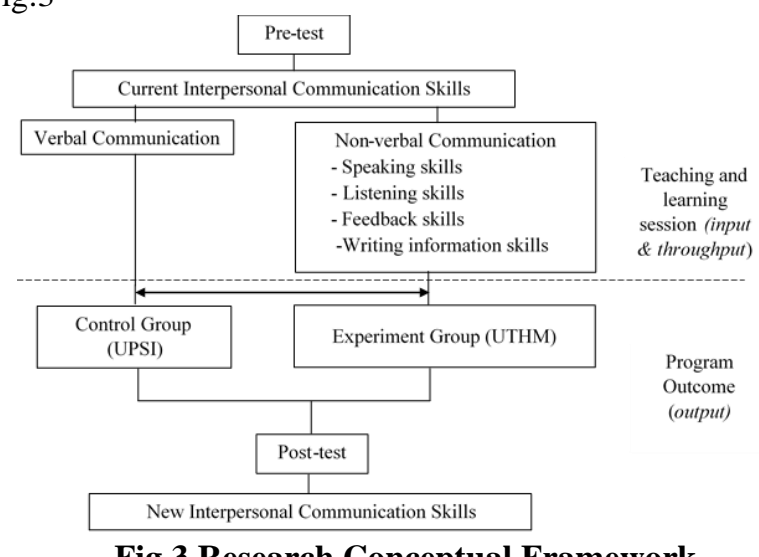

Fig.3 Research Conceptual Framework

\section{RESULT AND DISCUSSION}

A. The acquisition level of Interpersonal communication skill among prospective vocational teachers before undertakes Vocational Teacher Training (BIGV) Program (Pre-test)

Independent t-test analysis has been used to measure the differences on the acquisition level of interpersonal communication skills among two groups of education students; control group and experimental group. Result shows that there is no any significant difference between control group $(\mathrm{M}=164.735, \mathrm{SD}=24.404)$ and experiment group $(\mathrm{M}=170.191$, $\mathrm{SD}=16.273)$ among TVET students before undertakes Vocational Teacher Training Program (BIGV). Moreover, a smaller mean difference was recorded between both groups (mean difference $=5.456$, 95\% CI $=$ -.516 to 11.428 ) with the effect size of 0.016 . This indicate that students level acquisition on their interpersonal communication skills are strongly agreed to be the same on both groups. In accordance with the past research, this finding was similar with previous study performed by Mohd Amin (2011); Rajab \& Che Abas, Sulaiman \& Sapuan, Buntat \& Shahabudin Hassan, (2010); Yasin \& Seman, (2002); Tugiman, (1997) where the acquisition level of interpersonal communication skills among TVET practitioner were recorded at the lower level and sample has been taken among teacher, and university student population. Moreover, Yasin \& Seman (2002) and Yahaya et al., (2010) highlight the needs of communication skills as the most important criteria needed in nurturing the confident level among students. Hence, the improvement on TVET student acquisition level shall be highlighted so that the best quality of TVET graduates is possible to be achieved in the future.

Table 1: Independent t-test analysis for pre-test

\begin{tabular}{|c|c|c|c|c|c|c|c|c|c|c|c|}
\hline \multirow[t]{2}{*}{ Group } & \multirow[t]{2}{*}{$F$} & \multirow[t]{2}{*}{ sig. } & \multirow[t]{2}{*}{$t$} & \multirow[t]{2}{*}{$d f$} & \multirow[t]{2}{*}{$\begin{array}{c}\text { Sig. } \\
(2 \\
\text { Taile } \\
d)\end{array}$} & \multirow[t]{2}{*}{ Min } & \multirow[t]{2}{*}{$\begin{array}{c}\text { Standa } \\
\text { rd } \\
\text { Deviati } \\
\text { on }\end{array}$} & \multirow[t]{2}{*}{$\begin{array}{c}\text { Effe } \\
c t \\
\text { Size }\end{array}$} & \multirow[t]{2}{*}{$\begin{array}{c}\text { Mean } \\
\text { Differen } \\
\text { ce }\end{array}$} & \multicolumn{2}{|c|}{$\begin{array}{c}95 \% \\
\text { Confidence } \\
\text { Interval of } \\
\text { the } \\
\text { Difference }\end{array}$} \\
\hline & & & & & & & & & & $\begin{array}{c}\text { Low } \\
\text { er }\end{array}$ & $\begin{array}{c}\text { Uppe } \\
r\end{array}$ \\
\hline $\begin{array}{l}\text { Experim } \\
\text { ent }\end{array}$ & $\begin{array}{l}2.87 \\
2\end{array}$ & $\begin{array}{l}.09 \\
2\end{array}$ & $\begin{array}{l}1.80 \\
1\end{array}$ & $\begin{array}{l}20 \\
4\end{array}$ & .073 & $\begin{array}{l}170.1 \\
91 \\
\end{array}$ & 16.273 & .016 & 5.456 & -.516 & $\begin{array}{l}11.4 \\
28\end{array}$ \\
\hline Control & & & & & & $\begin{array}{l}164.7 \\
35\end{array}$ & 24.404 & & & & \\
\hline
\end{tabular}

\section{B. The acquisition level of Interpersonal communication} skill among prospective vocational teachers after undertakes Vocational Teacher Training (BIGV) Program (Post-test)

Independent t-test analysis has been used to measure the differences on the acquisition level of interpersonal communication skills among two groups of education students after undertakes Vocational Teacher Training (BIGV) Program. Result shows that there is no difference between control group $(M=158.674, S D=21.394)$ and experiment group $(M=164.076, S D=21.353)$. Moreover, a smaller mean difference was recorded between both mean difference $=5.402$, 95\% CI $=-1.945$ to 12.750 ) with the effect size of 0.011 . Moreover, score on post-test for control group and experiment group shows no any significant differences in which it indicates that there is no any impact of BIGV program towards prospective teacher for experiment group. However, there is improvement numbers recorded for min score in post test for experiment group after undertakes BIGV program compared to pre-test result. It can be stated that improvement has been found on the acquisition level of interpersonal communication skill among experiment group after entering the BIGV program. Hence, it indicates that this BIGV program statistically helps to strengthen the acquisition level of students in preparing them with adequate communication skill especially interpersonal skill.

\section{Table 2: Independent t-test analysis for post-test}

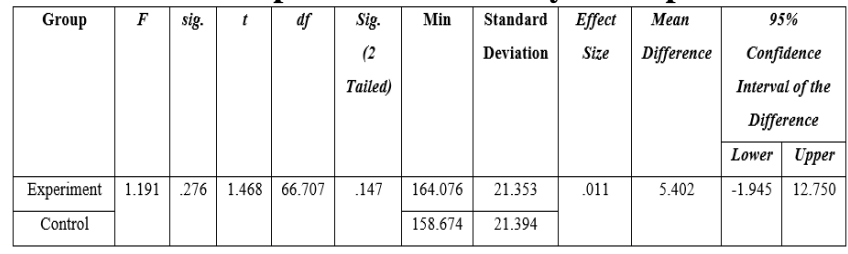

Published By:

Blue Eyes Intelligence Engineering 
This improvement had shown us that there are point of improvement can be taken in strengthening the better acquisition level of interpersonal skills achievement in the future. A previous study performed by Marzuki \& Don (2007) found that current teacher's interpersonal communication skills were still at moderate level and effort in increasing the level of acquisition are seems very crucial. Tamuri et al., (2004) also stated that there is still exist a few negative manners shows by teacher during teaching which making them be unrespectful by their students. Teacher is a like role model for the student and the weaknesses on having a good teacher personality may affect the decrement of attitude among student itself (Yahaya, 2005). Moreover, Ahmad et al., (2009) found that there is still exist a weakness in acquisition level of interpersonal skill among teacher. Teacher interpersonal communication skill are still at moderate level (Musa \& Halim, 2015; Marzuki 2002) and the efforts on strengthening the needs on skills acquisition level were still needed.

Hence, it can be clearly found that there is still a need on updating current needs on BIGV program even though research findings show no any significant differences recorded. It was advisable that efforts on keep improving personal quality of prospective teacher can be empowered so that prospective teacher able to survive within dynamic challenges exposure especially in this era of Industrial Revolution 4.0.

\section{CONCLUSION}

Industrial Revolution 4.0 is the era of technological application that empowered national economy towards the excellence quality of services and product that serves the nation. The needs on this new era of technological has bring us to a new exposure on the needs on empowering human that visible with the technological application. As in Malaysia scenario, education now is moving progressively in transforming the education to fulfill the current needs of Industrial Revolution 4.0 (Malaysian Insight, 2017). The requirement on high skill competency with dynamic personality to survive in Industrial Revolution 4.0 has put a great challenge to education sector in preparing the students to equip with the needs. As such, an adequate curriculum formulation is very crucial in determining the final quality of the graduates before they entering the working place. It was believed that this BIGV program is one of a good initiative that helps to impart with the efforts in producing a good quality of graduates especially prospective teachers' readiness. Result has shown that the interpersonal communication skills among prospective vocational teacher are set to be at high level and there is no any significant impact shown on the acquisition level of interpersonal communication skill after attending the BIGV program. However, some data have shown the increment value on min score of acquisition level for experiment sample group after attending the BIGV program. This indicate us that BIGV program was proven able to increase the acquisition level of skills among prospective vocational teachers and embarks the needs on keep updating the curriculum of BIGV program. The empowerment and revision on current learning activities performed throughout BIGV program shall be revised comprehensively so that a well-prepared prospective teacher can be produced in this era of Industrial Revolution 4.0. In the future practice, it was advisable that current education institution shall impart with Internet of Things (IoT) learning strategy so that learning and teaching strategy can be implemented in more interactive way and hence, students' interest towards subject matters can be increased significantly.

\section{ACKNOWLEDGMENT}

The authors would like to acknowledge all the research members of UTHM for their continuous support and commitment in ensuring the completion of this project. Our thanks are also dedicated to the Faculty of Technical and Vocational Education, UTHM, Faculty of Technical and Vocational, UPSI for their guidance and strong support in realizing this research. This research work is a fully-funded research awarded by the Research Management Center, Universiti Tun Hussein Onn Malaysia (UTHM) Johor under Geran MyRIVET, Vot No. K114.

\section{REFERENCES}

1. Ahmad, N. S., Amzah, F. \& Che Aman, R. (2009). Kemahiran komunikasi guru pelatih. Universiti Sains Malaysia. Jurnal Pendidik dan Pendidikan 24: 125-142.

2. Buntat, Y. \& Shahabudin Hassan M. (2010). Kemahiran Komunikasi dalam Meningkatkan Keyakinan Diri Pelajar: Satu Tinjauan di Kalangan Ahli Jawatankuasa Kolej Mahasiswa. Universiti Teknologi Malaysia. Diakses dari http//eprits.utm.my/2107/

3. Campbell, D. T., \& Stanley, J. C. (1963). Experimental and quasi-experimental designs for research on taching. In. N. L. Gaga (Ed.), Handbook of research on teaching (pp. 171-246). Chicago, IL: Rand Mcnally.

4. Chua, Y. P. (2006). Kaedah dan Statistik Penyelidikan, Buku 1. Universiti Putra Malaysia. McGraw Hill.

5. Dale, C., (1956). How To Develop Self-Confidence and Influence People by Public Speaking. New York: Pocket Books.

6. Guat, T. M. (2013). Komunikasi interpersonal dalam kalangan pelajar institut pendidikan guru semasa praktikum. Jurnal Penyelidikan IPG, Jil. 11.

7. Kementerian Pengajian Tinggi Malaysia, \& Kementerian Pelajaran Malaysia. (2005). Penilaian Latihan Mengajar Dalam Program Pendidikan Guru Di Malaysia. Pulau Pinang: Jawatankuasa Penyelarasan Pendidikan Guru (JPPG) Malaysia, Pusat Pengajian Ilmu Pendidikan, Universiti Sains Malaysia.

8. Illias, M. F., Mat Razali, A. S., Mohd Pisol, M I \& Sulaiman, M S.,(2016). Kemahiran Interpersonal Sebagai Asas Pembentukan Kemahiran Bermasyarakat. Conference of Muslim Society (CMS2016). Fakulti Pendidikan KUIS. Kolej Universiti Islam Antarabangsa Malaysia.

9. Marzuki, S. (2002). Ciri-ciri guru unggul: Satu kajian kes di beberapa buah sekolah menengah di Malaysia. Jurnal Pendidikan 22: 97-110.

10. Marzuki, S. \& Don, Y. (2007). Kecerdasan Emosi dan Kepimpinan Pendidikan dalam Pembentukan Sekolah Berkesan. Masalah Pendidikan 30(1). 113-125

11. Md. Salleh, F., (1995). Teori dan Amalan Kaedah Pengajaran, Pembelajaran dan Penilaian. UKM: Penerbit UKM

12. Musa, K. \& Abd. Halim, H. (2015). Kemahiran Interpersonal Guru dan Hubungan dengan Pencapaian Akademik Pelajar. Jurnal Pendidikan Malaysia 40(2)(2015): 89-99

13. Mohd Amin, M. (2011). Kemahiran interpersonal guru di dalam P\&P Diakses dari http://web,uthm.edu.my/ps/thesis/educational/maifuza\% 20mohd\%amin.pdf

14. Mohamed, I., Asimiran, S., Ahmad, Shamsudin, A., \& Mohd Daud, S. (2014). Peranan Mentor dalam Program Bina Insan Guru. Jurnal Personalia Pelajar 17 (2014): 31-40

15. Rajab, A. \& Che Abas, A. I. (2010). Self-Concept and Communication Skills: A Focus Among UTM Final Year TESL Students. Diakses dari http//eprits.utm.my/5932/

Published By:

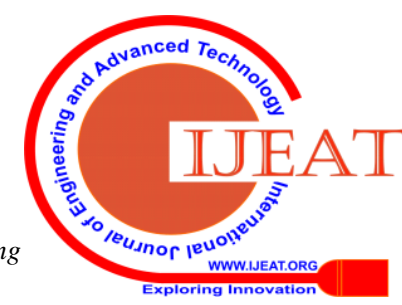


16. Sulaiman, H. \& Sapuan, N. H. (2010). Kemahiran Generik Yang Diperoleh Pelajar Sarjana Muda Teknologi Serta Pendidikan (Kemahiran Hidup) PKPG Semasa Menjalani Latihan Industri. Diakses dari http//eprits.utm.my/5945/

17. Tamuri, A. H., Yusopp, A., Osman, K., Abdul Razak, K., Awaludin, S. \& Abdul Rahim, Z. (2004). Kebersamaan pengajaran dan pembelajaran pendidikan islam ke atas pembangunan diri pelajar. Laporan Penelitian, Fakulti Pendidikan, Universiti Kebangsaan Malaysia dan Jabatan Pendidikan Islam dan Moral, Kementerian Pelajaran Malaysia.

18. Tengku Kasim. T. S. A. \& Abdurajak, F. S. (2018). Pengalaman Pengajaran Guru Novis Pendidikan Islam: Implikasi

19. terhadap Reka Bentuk Kurikulum Latihan Pendidikan Guru. Jurnal Pendidikan Malaysia 43(1)(2018): 59-66 DOI: http://dx.doi.org/10.17576/JPEN-2018-43.01-08

20. The Malaysian Insight. (2017). Sistem pendidikan tinggi negara perlu berubah . Kata menteri. 1 October. http://www. themalaysianinsight.com/bahasa/s/16768/. Retrieved on: 6 November 2017.

21. Tugiman, S. A. (1997). Tahap Kemahiran Menyelesaikan Masalah dan Komunikasi Dalam Kalangan Pelatih Kolej Kemahiran Belia Nasional (KKBN) Daripada Perspektif Tenaga Pengajar UTM. Diakses dar http//eprits.utm.my/2107/

22. Ulah, S., Mahamod, Z., Badusah, J. \& Yamat, H. (2012). Amalan komunikasi interpersonal direktif guru Bahasa Indonesia ketika memulakan pengajaran. Jurnal Pendidikan Bahasa Melayu 2: 71-83.

23. Widya, P. (2013). Peranan Komunikasi Interpersonal Guru Dalam Meningkatkan Pengetahuan Anak. Journal "Acta Diurna" Vol I.No.I

24. Yahaya, A., Ismail, S., Abdul, A. H. \& Ma'alip, H. (2010). Kaedah Mengajar dan Kemahiran Interpersonal Guru. Kuala Lumpur: PTS Professional Publishing Sdn. Bhd.

25. Yahaya, A. S. (2005). Mengurus Sekolah. Kuala Lumpur: PTS Profesional Publishing Sdn. Bhd.

26. Yasin, M. \& Seman, J. (2002). Tahap Komunikasi Interpersonal Murid-murid Sekolah Rendah Di Jajahan Tumpat, Kelantan. Diakses dari http//eprits.utm.my/5945/

\section{AUTHORS PROFILE}

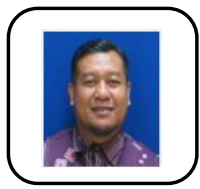

Ts. Dr. Hasyamuddin Bin Othman received his Bachelor of Manufacturing Engineering from Institut Teknologi Tun Hussein Onn (ITTHO) in 1997 and Master of Technical Education from University Technology Malaysia (UTM) in 1999. He was awarded PhD from University Technology Malaysia (UTM) in 2016. He is currently a lecturer from Faculty of Technical and Vocational Education (FPTV) University Tun Hussein Onn Malaysia (UTHM). He is a member of Malaysia Board of Technologists (MBOT). He has over 15 years of teaching experience and 5 years of research experience. His research interest is in Problem-Based Learning (PBL), Employability Skills, Technical, Vocational, and Engineering Education and Training, Mechanical and Manufacturing Product, Machining Skills and Operations, Ergonomic Design and Community and Environmental.

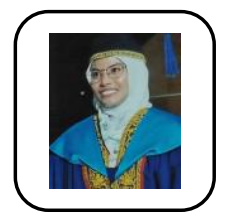

Norathirah Nabila Binti Abd Mutalib received he Bachelor of Science (Mathematics) (Hons) from University Kebangsaan Malaysia (UKM) in 2016 and received her practical training at Pejabat Setiausaha Kerajaan Negeri Perak (SUK Perak) under State Economic Planning Unit. She continued his study at master level and have been awarded Master of Technical and Vocational Education from University Tun Hussein Onn Malaysia (UTHM) in 2019. She is currently a PhD student in UTHM. Her research work is a fully-funded research awarded by the Research Management Center, Universiti Tun Hussein Onn Malaysia (UTHM) Johor under MyRIVET, Vot No. K114, The Empowerment Of Malaysia TVET Student's Employability Skills Through PBL Teaching Method. Her research interest is in statistic, Employability Skills and TVET Education.

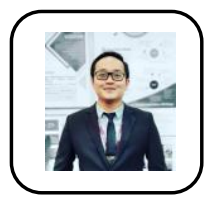

Reyanhealme Bin Rohanai received his Bachelor of Manufacturing Engineering (Manufacturing Management) (Hons) from Technical University of Malaysia (UTeM) in 2014. He continued his study at master level and has been awarded Master of Science (Industrial Engineering) from University Technology Malaysia (UTM) in 2016. After graduating his Master, he joined manufacturing industry as Engineer for almost 2 years and currently enrolled as a PhD student in UTHM. He is currently a lecturer from Faculty of Technical and Vocational Education (FPTV) University Tun Hussein Onn

Malaysia (UTHM). His research interest is in Industrial Engineering, TVET Graduate Employability and TVET Education. He has published 2 Scopus-indexed papers in International Conference, 2 publication papers under Khazanah Ilmu Berazam, 2 papers in Online Journal for TVET Practitioners and a paper in TVET Education. 